\title{
Сборка и анализ генома нефтеразлагающего штамма Rhodococcus erythropolis ВКПМ Ac-1659
}

\author{
Изотова А.О. ${ }^{1 *}$, Бахмутова Е.Д. ${ }^{1}$, Корженков А.А. ${ }^{1}$, Тощаков С.В. ${ }^{1}$, \\ Сидорук К.В. ${ }^{2}$, Бавтушный А.А. ${ }^{2}$, Патрушева Е.В. ${ }^{1,2}$, Патрушев M.В. ${ }^{1}$ \\ ${ }^{1}$ Национальный исследовательский иентр «Курчатовский институт», Москва, Россия \\ ${ }^{2}$ Национальный исследовательский центр «Курчатовский институт - ГосНИИгенетика», \\ Москва, Россия \\ *anu.izotova@mail.ru
}

Ключевые слова: сборка генома, анализ генома, деструкторы углеводородов

\begin{abstract}
Мотивация и цель: Представители вида $R$. erythropolis широко используются в технологиях биоремедиации как биоэмульгаторы и деструкторы углеводородов. В данной работе был секвенирован геном штамма R. erythropolis ВКПМ Ac-1659, выделенный из загрязненной нефтью почвы в Сибири. Целью работы были поиск и идентификация генов, определяющих способность штамма разлагать нефть.

Memodbl: Геномную библиотеку готовили с помощью KAPA HyperPlus ${ }^{\mathrm{TM}}$ Kit. Секвенирование проводили на Illumina MiSeq с использованием MiSeq Reagent Kit 500 v2. Контроль качества сырых прочтений осуществлялся с помощью пакета fastp v0.20.1. Сборка генома проводилась с помощью пайплайна ZGA (https://github.com/laxeye/zga/). Качество сборки оценивалось с помощью пакета CheckM. Аннотация генома была проведена при помощи NCBI Prokaryotic Genome Annotation Pipeline.
\end{abstract}

Pезультаты: Сборка генома состояла из 170 контигов общей длиной 6612324 п.н. и метрикой N50 664755 п.н. Анализ качества сборки по маркерным генам показал уровень полноты $99.94 \%$ и уровень контаминации $3.24 \%$. Таксономический анализ определил штамм как R. erythropolis. Анализ генетических путей деградации нефти выявил два кластера генов, отвечающих за первый этап утилизации алканов и включающих ген рубредоксинов, ген алкан 1монооксигеназы и ген регулятора транскрипции семейства TetR. Анализ метаболических путей показал наличие путей деградации жирных кислот, стероидов, бензоата, а также биосинтеза гема и кобаламина, ассимиляционного восстановления сульфатов. При этом пути метаболизма полиароматических углеводородов выявлены не были.

Bblвoдbl: Сборка и анализ генома штамма R. erythropolis Ac-1659 позволили на основании полученных данных произвести таксономическую идентификацию штамма. Функциональный анализ генов позволил выявить два кластера генов, определяющих способность штамма эффективно разлагать алифатические углеводороды.

Доступность данных: Геном доступен в NCBI GenBank под номером JAGVVT000000000.1. Необработанные прочтения доступны в NCBI SRA под номером SRX10910539.

Благодарности: Соглашение с Минобрнауки № 075-15-2019-1659 от 31.10.2019. 